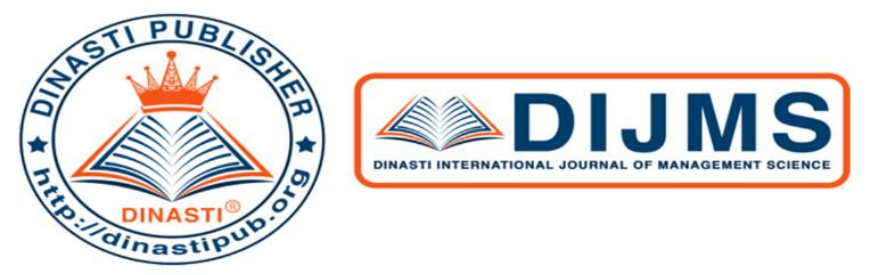

$+6281387654578$

+6281387654578 (Q)

https://dinastipub.org/DIJMS (8)

dinasti-info@gmail.com (๑)

\title{
DESIGNING BUSINESS CANVAS MODEL AND ANALYSIS BUSINESS IN WARUNG DIMSUM
}

\section{Kartika Nurhayat ${ }^{1}$}

${ }^{1)}$ Universitas Mercu Buana, Jakarta, Indonesia

\section{ARTICLE INFORMATION}

Received: $17^{\text {th }}$ May 2020

Revised: $20^{\text {th }}$ June 2020

Issued: $19^{\text {th }}$ July 2020

Corresponding author:

Kartika Nurhayat

E-mail:

Kartika.nurhayat02@gmail.com

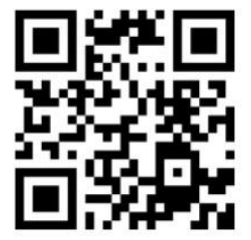

DOI:10.31933/DIJMS
Abstract: The development of culinary business is increasing in Indonesia, especially in big cities, making promising business opportunities. Warung dimsum are used as research objects for the application of Business Model Canvas. The research method uses quantitative descriptive. Data collection is done by interview. The results of the interview show that the Key Activity element is the strongest in the Warung Dimsum. Suggestion from research is that there is a need to develop channel elements to expand sales.

Keywords: Business Model. Business Model Canvas, Culinary

\section{INTRODUCTION}

The culinary business is growing rapidly in Indonesia because food and beverages are the most basic needs, food and beverages needed by humans to survive and carry out activities. Food and beverage needs continue to increase along with population growth, especially in big cities in Indonesia. Culinary has become a lifestyle of the community because of the growing development of innovation in food and beverage products. Asosiasi Perusahaan Jasaboga Indonesia (APJI) also played a role in achieving the growth of the food and beverage industry. This food and beverage sector, is able to provide the highest contribution with growth of $12.7 \%$ in 2018. (Tridhendrawan, 2019)

Continued growth in the food industry making the culinary business provide business opportunities for the community. Culinary business opportunities have a pretty good prospect and are easier to run because it is a basic human need. entrepeneur must take advantage of the lifestyle of the community who are like to gather with friends or family at the Restaurant or 
Cafe. Business is indeed much in demand by the community because it has its own satisfaction in managing it. If the business can be run well it will generate substantial income and can provide jobs for others. But people who want to start a business must know the basic of a business to facilitate the business.

The researcher chooses Warung Dimsum to be the object of research. Warung Dinsum is one of UKM in Bandung which is engaged in food selling dimsum. Warung Dinsum has promising business opportunities but the business model has not yet been implemented as long as the business is initiated. The business model is important in pioneering an effort to be able to explain about the business with the aim that it can consider changes for the progress of the business (Daryanto, 2016). The use of the business model that will be applied will be guided by the canvas business model developed by Osterwalder.

\section{LITERATURE REVIEW}

\section{Business Model}

Business development is growing rapidly, but most people are not familiar about the basic of a business. The business model is important in pioneering an effort to be able to explain about the business with the aim that it can consider changes for the progress of the business (Daryanto, 2016). Talk of business models blossomed in the 1990s (Amit and Zott, 2001), and the concept has continued to gain popularity ever since (Ghaziani and Ventresca, 2005; Zott et al., 2011). The purpose of a business model is to describe the general logic of the business including business value, the customer segment, organisation and financing (Bouwmann et al. 2008). Business models describe what kind of value a business is delivering and how this is generated and communicated to customers. Teece (2010, p. 191) The concept of a business model must be simple, relevant, and easy to understand intuitively without the intention of simplifying very complex company functions. (Osterwalder \& Pigneur, 2010).

\section{Business Model Canvas}

Business Model Canvas is a business model of a logical picture of how an organization creates, delivers and captures value (Osterwalder, 2010). According to Cunningham, Ian, Graham Dawes and Ben Bennet(2017), business strategies implemented by companies will not be able to run optimally if they do not base on the assessment and formulation of the right business model. Inspire business success throughout the world and receive profits from companies using Canvas Model Business. According to Aaker(2018), it was identified that Business Model Canvas is a tool to support the development of intelligent service concepts to customers. Business Model Canvas can be used for all business sectors and can assist in the process of analyzing business needs, weaknesses and strengths.

The business model of Canvas can be explained through nine fundamental elements that show how to think about how organizations generate profits (Osterwalder and Pigneur, 2009). The Business Model Canvas is very concise, easy to understand and quite interesting. 
The concept of the Canvas business model consists of nine fundamental elements that show the logic of developing profits for the company. These elements are Customer Segment, Value Proposition, Channels, Customer Relationship, Revenue Stream, Key Resources, Key Activities, Key Partners, Cost Structure. (Osterwalder and Pigneur, 2010).

\section{Customer Segment}

Customer segments are distinctions of human groups or organizations to determine their objectives. To provide satisfaction to customers, segmentation is needed so that they can focus more on developing business strategies for specific customer segments according to their characteristics, habits and needs. (Osterwalder and Pigneur, 2010) Customer is an important element in all businesses. Businesses are recommended to conduct an analysis of consumer needs which are divided into several categories. According to Osterwalder and Pigneur(2011), the customer segment can be categorized into: mass market, niche market, segmented, diversified, multilateral platform or multilateral markets.

\section{Value Proposition}

Value Propositions are a variety of products and services that will create value for certain segment customers. Product quality is a factor to support purchasing decisions, (Brata, 2017). The main reason customers switch one product or service to another is whether they actually know which product or service solves the problem, or satisfies the primary need.(Piñeiro, Et Al, 2017) The value of a product or service for consumers can be in the form of price, design, product usability.

\section{Channels}

Channels is a medium for companies to communicate with their customers to convey a value proposition. (Osterwalder and Pigneur, 2010) Channel has a function to increase knowledge about products or services to consumers. Another important function is to provide them with support after purchase. According to Osterwalder and Pigneur (2011), the phases that permeate this component are characterized in detail in the following aspects: knowledge, evaluation, purchase, delivery and after-sales. To take the value proposition, the organization can choose a direct and private channel that involves sales staff, sales or own stores.

\section{Customer Relationship}

Customer Relationships explains about maintaining relationships between companies and consumers. The company must explain the type of relationship each customer segment wants to build. Various types of relationships ranging from providing personal assistance to individuals to each consumer, utilizing the community, or even in the form of "self-service". (Osterwalder and Pigneur, 2010). According to Osterwalder and Pigneur(2011), these relationships go through personal and even automated aspects. Relationships can be focused on the following motivations: a) conquer the client; b) retain the customer and c) increase sales. 


\section{Revenue Stream}

Revenue streams are income received by the company from its customers on value propositions given by the company to customers. According to Piñeiro, Et Al, (2017), there are two different types of revenue sources that may be in a business model, they are: a) income transactions resulting from single payment and b) recurrent income, resulting from the constant payment, coming from the delivery of a proposal of Value to customers or aftersales support.

\section{Key Resource}

Key Resources explains the most important assets needed to make a business model work well. Every business model requires key resources. (Osterwalder and Pigneur, 2010) These key resources enable companies to create and offer value propositions, reach markets, maintain relationships with customers, and earn revenue. According to Piñeiro, Et Al, (2017), The main resources can be physical (buildings, machines, systems, points of sale and distribution networks); (Trademarks, scientific knowledge, patents, registers, partnerships and database); Human beings (people and their abilities); And financial (money, credit lines, as well as crucial actions to hire employees).

\section{Key Activities}

Key Activities describe the most important things that a company must do to make its business model work.(Osterwalder and Pigneur, 2010) According to Piñeiro, Et Al, (2017), Usually, these activities fall into one of the three groups presented below: a) production: relative to the product in a manufacturing; b) problem solving: relate to services provided and c) platform / network: mainly related to business on the internet.

\section{Key Partners}

Key partnerships describe the network of suppliers and partners that make business models work well. Companies form partnerships for various reasons, and partnerships form the basis of many business models. Companies create alliances to optimize their business models, reduce risk, or obtain resources. (Osterwalder and Pigneur, 2010) Some types of partnerships are punctuated by Osterwalder and Pigneur (2011) and are distinguished in four different types that are: strategic alliances between non-competitors; Competition (strategic partnerships between competitors); Joint ventures to develop new business; And the buyersupplier relationship in order to ensure reliable supplies. Piñeiro, Et Al (2017)

\section{Cost Structure}

The Cost Structure describes all costs incurred for operating a business model. Cost structure describes the most important costs that occur when operating in a particular business model. Creating and delivering value, maintaining customer relationships, and generating revenue are all charged. (Osterwalder and Pigneur, 2010) 


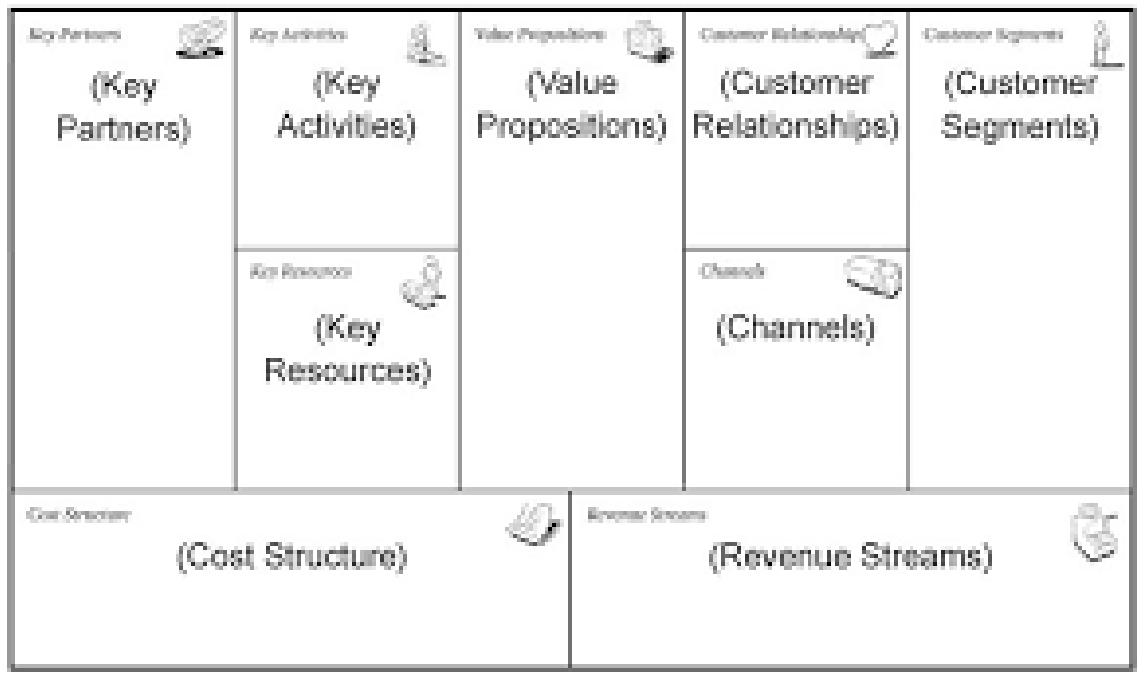

Pictire 1. Business Model Canvas Source: Osterwalder \& Pigneur (2010)

\section{RESEARCH METHODS}

The research method used is quantitative descriptive which method aims to solve problems in the company today. According to Sugiyono (2008), descriptive is research conducted to determine the value of an independent variable, either one or more variables (independent) without making comparisons or connecting with other variables.

In gathering information and data for designing a canvas model business, the reseacher uses the interview method with the co-owner. After the initial business model is discussed in the interview and evaluated in the interview with the parties discussed earlier, the canvas business model will be rearranged in accordance with the evaluation of the interview that has been conducted. After that, a validated canvas business model will be presented

\section{RESULTS AND DISCUSSION}

Warung Dimsum is one of UKM in Bandung which is engaged in food selling dimsum. Warung Dimsum was first established in 2016 by selling frozen dimsum by relying on purchases from suppliers. The development of dimsum sales is quite good and has many orders for certain categories. This causes orders from suppliers to not be fulfilled so they decide to produce their own dimsum. Warung dimsum also develops sales by opening shops and opening resellers for Jabodetabek and West Java.

In describing the business model at Warung Dimsum by using the Business Model Canvas consisting of 9 elements, namely: customer segments, value dkey partnerships, and cost structure.

\section{Customer Segment}


The customer segment targeted by Warung Dimsum is all circles. Dimsum is a food that is loved by many people so that its segmentation is quite broad. With a variety of seafood and non-seafood flavors make consumers easily accept these types of food. The price is very affordable for student consumers, workers or housewives.

\section{Value Proposition}

In determining the value proposition in the Warung Dimsum, the results are as follows:

- Taste

Where Warung Dimsum pay attention to the taste of all the food. When Warung Dimsum began to try food production without the help of suppliers, the experiment continued until it produced a taste that was very popular with consumers.

\section{- Cleanliness}

Cleanliness is one of the important things in the food business. In the production process, staff are required to use masks, gloves, production sandals and headgear so that food hygiene is maintained.

- Fresh ingredients

Good taste does not escape from quality ingredients. Foodstuffs used by Warung Dimsum are fresh ingredients where they are sent every morning because they are produced on the same day.

\section{- Product innovation}

Product innovation is continuously carried out to maintain the quality of Warung Dimsum and continue to compete with competitors. Examples of product innovation are somay taichan, somay nori, chili oil and somay mushrooms.

\section{Channels}

A channel is a way for companies to convey consumer information and deliver value propositions. In this element Warung Dimsum have several channels:

- Social media

The use of Instagram social media is a form of information to consumers. In Instagram, it can simultaneously attract consumers because of the content provided. Production information, new products and consumer testimonials are informed via Instagram because many people use the Instagram application.

In online sales via Warung Dimsum collaborating with gofood and grabfood to facilitate consumers in ordering food because the application is widely used by consumers. For other communication can be done via whatsapp, booking via chat is more widely used for reseller bookings because in large numbers.

- Shipping expedition 
In this channel, shipping expeditions have a very important role for food distribution. Due to the large number of resellers from outside Bandung, the distribution is carried out by a third party. Resellers from Warung Dimsum come from Jabodetabek and responsible so shipping is done by train, travel or food expedition (Paxel).

\section{Customer Relationship}

Relations with consumers is one of the important things that must be maintained. The strategy undertaken by Warung Dimsum is to maintain good communication with all retail consumers and resellers. Good service continues to be done such as continuing to maintain the flavor of food, cleanliness and being friendly to consumers. In terms of flavors, Warung Dimsum survey consumers about food flavors so that consumers can provide feedback and the feedback results become input for Warung Dimsum to continue to improve.

The implementation of discount and free postage promotions is also given to consumers, the strategy is carried out in collaboration with grabfood.

\section{Revenue Stream}

In a restaurant business, the type of revenue streams is transaction revenue, which means that revenue is derived from one-time consumer payment. Consumers come to a restaurant, then eat, and pay at the same time on the same day, no further payment or credit (Boedianto, 2015).

In this element, the source of income from Warung Dimsum is all sales from all consumers. Consumers from Warung Dimsum are divided into 3 categories namely retail consumers, resellers and wedding events.

\section{Key Resources}

In the key resource element, Warung Dimsum are divided into several parts, namely physical assets, building assets, HR assets.

Physical assets are used to support the production and sales process of food sold by Warung Dimsum. The milling machine is a machine for processing fresh meat to be used as a dimsum dough, a milling machine that is used large enough so that the products produced are sufficient to fulfill the orders of all consumers. Next is a blender that is used to smooth the seasonings for dimsum dough and other supporting assets are freezers that are used to store food produced from production to keep it fresh.

The building assets owned by Warung Dimsum are production houses and food stalls for retail consumers. Where the two buildings have become personal assets of Warung Dimsum so no rental fees are required.

HR assets (Human Resources) owned by Warung Dimsum are employees for the production team, sales team in the store (bandung).

\section{Key Activities}

The key elements of Warung Dimsum carry out the following activities: 


\section{- Research and Development}

This activity is the beginning of making dimsum food. Starting from the lack of orders obtained from suppliers so it gives an idea to produce dimsum so it does not depend on supplier stock. Beginning to try to produce somay by continuing to experiment with flavors so as to get flavors that are considered quite satisfactory.

Food product development continues to be done by trying to manufacture somay nori, somay mushrooms, somay taichan and chili oil. For chilli oil flavor, the beginning of making produces a pretty spicy taste but because consumers make a request to add spicy flavor so that the flavor is improved by adding dried chillies so that the resulting flavor becomes very spicy. The new flavor of chili oil makes sales increase so that the flavor continues to be maintained.

\section{- Purchase of raw materials}

This process purchases raw materials from suppliers such as chicken, eggs, seasonings, crabstick, and other ingredients. For fresh raw materials done every morning because when producing dimsum must use fresh ingredients.

\section{- Production}

Where the process of making dimsum is done at the production house. Dimsum production is carried out daily for customer orders for resellers and dimsum stalls. The results of production in the form of frozen dimsum so that consumers can cook it at home or directly eat at dimsum stalls.

- Sales

The next activity is selling food products to consumers. Sales are done by resellers or retail consumers.

- Shipping

The last activity is food delivery. Where after consumers order dimsum, employees will do the packaging process and send food via expedition,

\section{Key Partners}

Collaboration with partners must be maintained properly in order to expedite business processes. Suppliers or suppliers of food raw materials are the most important partners because Warung Dimsum are very dependent on the food raw materials sent. In maintaining good relations with suppliers, Warung Dimsum will continue to make orders to these suppliers and make payments on time so that raw materials sent always receive priority.

Other collaboration is carried out with promotional media that play a role in product branding and building engagement with consumers. The media is done by advertising on Instagram and working with photographers to make product photos.

\section{Cost Structure}


The cost structure of a Warung Dimsum is as follows:

- Production material

Costs used to buy raw materials and tools to support product production

- Operating costs

Costs used to provide wages to employees and accommodation costs.

- Marketing costs

Costs used to do product marketing by doing product photos by photographers and advertisers on Instagram.

\section{CONCLUSIONS AND SUGGESTIONS}

Based on the results of interviews and data analysis on the business model canvas on Warung Dimsum, the conclusions of this study are as follows:

- Of the 9 fundamental elements of the canvas business model. The most powerful element is key activities because dimsum production is the main activity carried out to fulfill consumer orders.

- Next is the value proposition element because the value provided already meets the needs of consumers.

- The element that needs to be evaluated is the channel element because marketing has not been done in all media, and can still be developed again.

Suggestions that writers can give to this research are :

- It is necessary to add marketing media such as market place (Shoppe / Tokopedia) because it can increase sales turnover and product branding to a wider market

- Resellers from Warung Dimsum are from Jabodetabek and the answer is because the delivery of frozen food products cannot be more than 12 hours outside the freezer. Warung Dimsum can use dry ice for product packaging so consumers outside the island can order the product

- To increase consumer and product branding, Warung Dimsum are better off opening branches in other cities such as Jakarta

- There needs to be a comparison of business models with other business models so that they can find business models and better knowledge for the future.

\section{REFERENCES}

Amit, R. and C. Zott (2001).Value Creation in e-Business. Strategic Management Journal Vol 6-7(22), pp493-520 
Boedianto, L.P and Harjanti,D. (2015). Strategi Pengembangan Bisnis Pada Depot Selaris Dengann Pendekatan Business Model Canvas. AGORA Vol. 3(2) pp292-301

Bouwmann, H de Vos, H. Haaker, T. (2008) "Mobile Service Innovation and Business models" Springer, Berlin

Brata, BH., Husani, S., Ali, H. (2017). The Influence of Quality Products, Price, Promotion, and Location to Product Purchase Decision on Nitchi At PT. Jaya Swarasa Agung in Central Jakarta. Saudi Journal of Business and Management Studies. Vol-2, Iss-4B (Apr, 2017):433-445 433-445

Cunningham, Ian, Graham Dawes, and Ben Bennet. (2017). The Wisdom and Strategic Learning, Second Edition. USA: Routledge

D. A. Aaker, (2018). Strategic Marketing Management. Salemba Empat: Jakarta.

Daryanto, R. (2016). Bisnis Model Kanvas. Bandar Lampung.

Ghaziani, A. and Ventresca, M.J. (2005).keywords and cultural change: frame analysis of business model public talk, 1975-200. Sociological Forum 20 (4) pp523-559

Gierej, S. (2017). The Framework of Business Model in the Context of Industrial Internet of Things. Procedia Engineering, Vol 182, 206-212.

Osterwalder, A. and Pigneur, Y. (2009). Business model generation: A handbook for visionaries, game-changers, and challengers. Self-published.

Osterwalder, A and Pigneur, Y. (2010). Business model generation: a handbook for visionaries, game changers, and challengers. New Jersey: John Wiley \& Sons, Inc.

Osterwalder, A and Pigneur, Y.(2011).Business Model Generation: inovação em modelos de negócio. Rio de Janeiro: Alta Books.

Piñeiro, F.Et Al (2017). Business Models On Startups : A Multicase Study. Vol 10(5), pp792807

Sugiyono. 2008. Metodologi penelitian Kuantitatif, Kualitatif, dan R\& D. Bandung: Alfabeta.

Teece, D. J., (2010), Business Models, Business Strategy, and Innovation. Long Range Planning, Vol 43(2-3), pp172-194

Trihendrawan, N.(2019). Sektor Kuliner Indonesia Tumbuh 12,7\%. [Online] Tersedia : https://ekbis.sindonews.com/berita/1388028/34/sektor-kuliner-indonesia-tumbuh-127.

[Di akses 16 Mei jam 23.00]

Zott, C., Amit, R., \& Massa, L. (2011). The business model: recent developments and future research. Journal of Management, Vol 37 (4), pp1019-1042 